capsules. Although the proportion of patients receiving oral olsalazine ( $2 \mathrm{~g}$ daily) who had a good clinical response was greater than the proportion receiving placebo who did so, the most striking difference between the two groups was the clinical deterioration seen in those receiving the placebo. Greater clinical benefit might therefore be seen with longer periods of treatment or higher doses of olsalazine.

In both trials the response of those receiving placebo was high, of the order of $40 \%$. Some studies have yielded similarly high rates of response to placebo, ${ }^{12-16}$ although others have reported rates of 20 $30 \% .^{6}{ }^{17}$

The failure to obtain a significant response to olsalazine enemas was surprising. Enemas of $\mathrm{N}$-acetyl 5 -aminosalicylic acid or 4aminosalicylic acid, given according to a similar protocol, have resulted in significant rates of response. ${ }^{14}{ }^{17}$ It is conceivable that olsalazine was not adequately split to deliver two molecules of 5aminosalicylic acid when administered as an enema. No data are available on this point, but as all patients in this trial were able to retain the enema this seems an unlikely explanation.

Sulphasalazine itself is not a powerful drug for the treatment of active ulcerative colitis and is considerably less effective than corticosteroids.$^{18}$ Its principal use is in maintaining remission, and it is for this that olsalazine has been developed. Trials comparing olsalazine with sulphasalazine in the long term are now in progress.

WSS, GDB, and AI were in receipt of fellowships in gastroenterology from the University of Oxford. We thank Dr S C Truelove for his helpful advice and criticism and Pharmacia for support and for supplying materials.

\section{References}

1 Dissanayake AS, Truelove SC. A controlled therapeutic trial of long-term maintenance treatment of ulcerative colitis with sulphasalazine (Salazopyrin). Gut 1973;14:923-6.

2 Taffet SL, Das KM. Sulphasalazine—adverse effects and desensitization. Dig Dis Sci 1983;28: 833-42.

3 Das KM, Eastwood MA, McManus JPA, Sircus W. Adverse reactions during salicylazosulphapyridine therapy and the relation with drug metabolism and acetylate phenotype. $N \mathrm{Engl}$ f Med 1973;289:491-5

4 O'Morain C, Smethurst P, Dore CJ, Levi AJ. Reversible male infertility due to sulphasalazine in studies in man and rat. Gut 1984;25:1078-84.

5 Khan AKA, Piris J, Truelove SC. An experiment to determine the active moiety of sulphasalazine. Lancet 1977;ii:892-5.

6 Van Hees PAM, Bakker JH, Van Tongeren JHM. Effect of sulphapyridine, 5-aminosalicylic acid, and placebo in patients with idiopathic proctitis: a study to determine the active therapeutic moiety of sulphasalazine. Gut 1980;21:632-5.

7 Klotz U, Maker K, Fischer C, Heinkel K. Therapeutic efficacy of sulphasalazine and its metabolites in patients with ulcerative colitis and Crohn's disease. N Engl f Med 1980;303:1499502 .

8 Willoughby CP, Aronson JK, Agback H, Bodin NO, Truelove SC. Distribution and metabolism in healthy volunteers of disodium azodisalicylate, a potential therapeutic agent for ulcerative colitis. Gut 1982;23: 1081-7.

9 Lauritsen K, Hansen J, Ryde M, Rask-Madsen J. Colonic azodisalicylate metabolism determined by in vivo dialysis in healthy volunteers and patients with ulcerative colitis. Gastroenterology 1984;86: $1496-500$

10 Jewell DP, Truelove SC. Disodium azodisalicylate in ulcerative colitis. Lancet 1981;ii:1168-9.

11 Truelove SC, Witts LJ. Cortisone in ulcerative colitis. Br Med f 1955;ii: 1041-8.

12 Dick AP, Gravson MJ, Carpenter RG, Petrie A. Controlled trial of sulphasalazine in the treatment of ulcerative colitis. Gut 1984;5:437-42.

13 Truelove SC, Richards WCD. Biopsy studies in ulcerative colitis. Br Med 7 1956;i: 1315-8.

14 Selby WS, Bennett MK, Jewell DP. Topical treatment of distal ulcerative colitis with 4 Selby WS, Bennett MK, Jewell DP. Topical treatmen
aminosalicylic acid enemas. Digestion 1984;29:231-4.

15 Baron JH, Connell AM, Lennard-Jones JE, Jones FA. Sulphasalazine and salicylazosulphadimidine in ulcerative colitis. Lancet 1962;i: 1094-6.

16 Binder V, Halskov S, Hvidberg E, et al. A controlled study of 5-acet-aminosalicylic acid (5-AcASA) as enema in ulcerative colitis. Scand f Gastroenterol 1981;16:1122.

17 Willoughby CP, Piris, J, Truelove SC. The effect of topical $N$-acetyl-5-aminosalicylic acid in ulcerative colitis. Scand $\mathcal{F}$ Gastroenterol 1980;15:715-9.

18 Truelove SC, Watkinson G, Draper G. Comparison of corticosteroid and sulphasalazine therapy in ulcerative colitis. Br Med f 1962;ii:1708-11.

(Accepted 5 September 1985)

\title{
Possible mechanism for mianserin induced neutropenia associated with saturable elimination kinetics
}

\author{
J L O'DONNELL, J R SHARMAN, E J BEGG, B M COLLS, P W MOLLER
}

\begin{abstract}
Two cases of mianserin induced neutropenia associated with prolonged elimination of the drug were studied. In each case the pharmacokinetic profile suggested saturable elimination kinetics, and the temporal relation of mianserin concentrations and the neutrophil count suggested a direct toxic effect of mianserin on the bone marrow.

Until further studies are carried out the plasma mianserin concentration and neutrophil count should be measured in any patient who develops an infection while taking this drug.
\end{abstract}

\footnotetext{
Departments of Medicine and Clinical Biochemistry, Christchurch Hospital, Christchurch, New Zealand

J L O'DONNELL, MB, CHB, medical registrar

J R SHARMAN, BSC, toxicologist

E J BEGG, FRACP, clinical pharmacologist

B M COLLS, FRACP, FRCP, consultant physician

PW MOLLER, FRCP, FRACP, rheumatologist

Correspondence to: Dr Begg, department of medicine.
}

\section{Introduction}

Mianserin is a tetracyclic antidepressant which has occasionally caused severe blood dyscrasias.' Pharmacokinetic studies of the drug in 14 elderly patients showed a terminal elimination half life of $27 \cdot 0$ (SD 13.1) hours, while in eight healthy adults it was $9 \cdot 6(1.9)$ hours. ${ }^{2}$ Saturable elimination kinetics-as seen, for example, with phenytoin-has been said not to occur with mianserin. ${ }^{3}$ We report two cases of mianserin induced neutropenia associated with prolonged elimination of the plasma concentrations, which declined in a manner suggesting that the metabolising enzymes were saturated.

\section{Case 1}

A 60 year old woman was found to be neutropenic $\left(0.034 \times 10^{9} / 1 ;\right.$ normal range $\left.2 \cdot 0-8 \cdot 0 \times 10^{9} / \mathrm{l}\right)$ when she presented with a febrile illness due to right otitis externa. She had been prescribed mianserin $30 \mathrm{mg}$ daily six weeks before instead of her usual amitriptyline. Other medications included labetalol $100 \mathrm{mg}$ twice daily and hydrochlorothiazide $50 \mathrm{mg}$ and amiloride 5 $\mathrm{mg}$ daily. Liver function values were mildly abnormal.

The plasma mianserin concentration was high initially and declined only slowly when the drug was withdrawn. This is shown in the figure along with the serial neutrophil counts. The initial slope of the mianserin elimination curve showed a half life of about 6.5 days. The terminal elimination half life was roughly 23 hours. 
Her drugs were discontinued and she was treated with intravenous antibiotics. She was discharged on day 32 .

\section{Case 2}

A 73 year old woman presented after collapsing at home and was found to be febrile and neutropenic $\left(0.7 \times 10^{9} / 1\right)$. Six weeks earlier dothiepin hydrochloride had been replaced by mianserin $60 \mathrm{mg}$ daily. Other medication was labetalol $200 \mathrm{mg}$ twice daily and triazolam at night. Liver function values were moderately abnormal. The figure shows her serial plasma mianserin concentrations and neutrophil counts. The initial slope of the mianserin elimination curve showed a half life of approximately $7 \cdot 6$ days. The terminal elimination half life was roughly 10 hours.

Mianserin was discontinued on admission. Labetalol was continued to day 25 and withdrawn. Triazolam was continued throughout. She was discharged after 28 days.

\section{Discussion}

Although these patients were receiving recommended doses of mianserin, the initial high plasma concentrations and the slow, biphasic elimination suggest that the capacity of the metabolising enzymes had become saturated. This behaviour is similar to the pharmacokinetics of phenytoin, which also has saturable elimination kinetics. This has not previously been reported for mianserin. If toxicity is directly related to plasma concentrations the risk in patients with saturable enzymes is increased considerably.

Impaired liver function, possibly induced by mianserin, with subsequent improvement may explain the biphasic curves but in neither case was the dysfunction severe enough to make this likely. Inhibition of mianserin metabolism by other drugs is also possible. Both patients were taking labetalol. In case 1 all medications were stopped immediately on admission, whereas in case 2 labetalol was continued. Despite this, the mianserin curves in the two cases were similar. It therefore seems unlikely that labetalol altered the metabolism of mianserin.

The temporal relation between the plasma mianserin concentration and the neutrophil count in each case suggested a direct toxic effect of mianserin on the bone marrow.

Until more is known about saturable kinetics with mianserin we suggest that the white cell count and the plasma mianserin

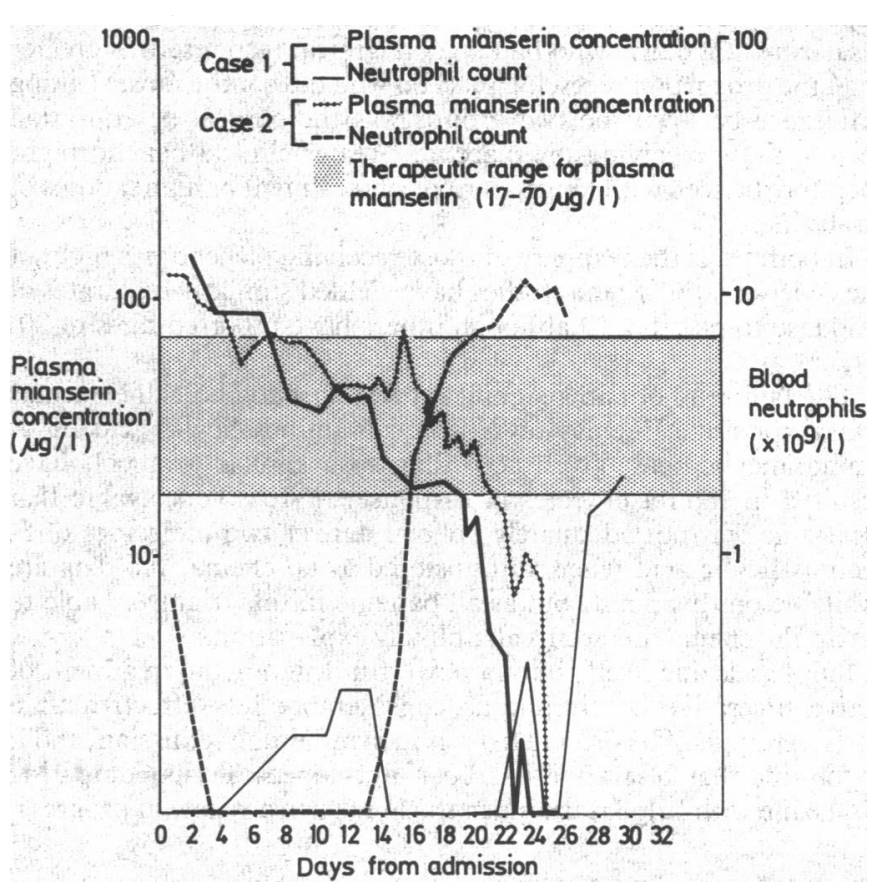

Serial plasma mianserin concentrations and neutrophil counts in cases 1 and 2 .

concentration should be checked in any patient who develops an infection while taking this drug.

We thank Miss V Elder for secretarial help.

\section{References}

1 Clink HM. Mianserin and blood dyscrasias. Br f Clin Pharmacol 1983;15:291-3S.

2 Shami M, Elliot HL, Helman AW, Whiting B. The pharmacokinetics of mianserin. Br $\mathcal{A}$ Cli尺 Pharmacol 1983;15:313-22S.

3 Van Der Veen F, De Ridder JJ, Vink J, Wijnand HP. Plasma levels of the antidepressant dru mianserin: relevance to clinical pharmacology and therapy. Ther Drug Monit 1980;2:95.

(Accepted 30 August 1985)

\section{YEARS AGO}

It is well known that the poor of large cities, and of large towns, do not obtain milk; but, it is the same also with very many of our moderately sized villages. It has recently been reported, by an inspector of the Local Government Board, that, in the ironstone villages of North Lincolnshire, milk is scarcely to be got for the 5,000 and more inhabitants, consisting almost solely of young married ironworkers and their families. It is so, too, even in dairy counties. In Somersetshire, for instance, it is no uncommon thing to see children, for want of milk, literally starving on water-sopped bread. The daily supply in such a county is either sent by train to the large towns, or turned into butter and cheese. No portion of the plenty remains for the poor of the place itself. The milk-supply of our people is a subject of engrossing interest. Milk is the natural food of mammals during the earliest term of life, and it is a well-established fact that, speaking generally of the several orders of mammals, the longer the period during which the new-born obtain maternal sustenance, the better fitted are they for the struggle for existence. Woman, however, in numberless instances, abrogates her natural function; the babe is unnaturally weaned from a life which should be spent in ready assimilation of specially assimilable material, to a life reduced by imperfect assimilation of materials, for which its digestive organs are not adopted. This is so of necessity among the hard-worked women of the labouring class, and more markedly in manufacturing towns. Milk, again, is the sheet-anchor of life in times of sickness. The greatest concern, in fact, attaches to the quantity and availability, as well as to the quality of our milk-supplies. There is one source of milk which is both plentiful and, we should suppose, within the means of the poorest of our population-tinned milk. This valuable food is certainly not rightly appreciated by the poor. There is, indeed, as great of prejudice against it as there is against flour containing the more superficia layers of the wheat-grain. It is to be regretted that these prejudices are rooted with such fixity. Much might be done by medical men, and medical officers. of health, to correct this misplaced, though natural repugnance to preserved milk, and other foods, as yet not rightly appreciated. We admit thas condensed milk is not to be compared in health-giving properties to fresh milk. It is, nevertheless, highly to be esteemed, and it might safely, and with the greatest advantage, enter very largely into every-day dietary. There will however, always remain an urgent demand for fresh milk. It cannot be justifiable for large owners of land to bring together workers from all parts? to turn their mineral-laden soil into pounds sterling, without making every attempt to provide for their essential wants; and of these we hold milk to beo one. It cannot be justifiable for large owners of pasture to send away everyt iota of the product of their dairies, or so to dispose of it that the poor around them are left absolutely destitute of this all-essential food. It is right however, to say that some landed proprietors are fully alive and equal to what we feel to be a duty in this matter. Some have, indeed, gone so far as to let? their land in lots of four to fifteen acres, and to demand of each tenant that he supply the village, in which he resides, with as much milk as is required before any is put aside for cheese- or butter-making. It is said that the plan pays, and it is, moreover, attended "with marked success, especially with the children, who have improved physically in various ways." It is to be hoped that it may be more generally practised. It is true that the value of condensed milk has yet to be learnt by very many; but it is none the less important that every effort be made to secure to the children of overworked mothers, and to the sick also, that food, the most useful of all foods, fresh milk. (British Medical fournal 1885;ii:1073.) 